\title{
BEYOND EXCEPTIONALISM:
}

\author{
NOTES ON THE ARTISANAL PHASE OF THE LABOUR \\ MOVEMENT IN FRANCE, ENGLAND, GERMANY AND THE \\ UNITED STATES*
}

\begin{abstract}
SUmmarY: The early labour movements in Western Europe and North America were all dominated by urban artisans, a fact reflected most clearly at the programmatic level by the prominence of demands for producers' cooperatives. This article presents a proposal for and an extremely brief sketch of a comparative investigation of this first phase of the labour movement in England, France, Germany, and the United States. Different aspects of class formation, such as the economic situation of the trades, the social relationships within them, or the role of artisanal and corporate traditions in artisanal politics and trade-union organization, are discussed. Comparative labour history, it is argued, must employ such a theoretical framework, one that allows the integration of the many dimensions of class formation; otherwise it will have to sacrifice whatever progress the last generation of labour historians has achieved.
\end{abstract}

\section{Introduction}

The early labour movements in France, Germany, the United States and, to a lesser degree, also in England were all dominated by urban artisans, with a rather small range of trades being clearly overrepresented. Tailors, shoemakers and cabinet-makers were usually the most prominent participants in the activities of early working-class organizations, while the journeymen of the building trades also played a considerable role. ${ }^{1}$ The same is, of

\footnotetext{
* The following is based on a lecture given to the conference of the Internationaal Instituut voor Sociale Geschiedenis on "The Formation of Labour Movements: Comparative Perspectives", held at Alkmaar, 31 May to 2 June 1990. I would like to thank the participants, especially Ray Markey, David Montgomery, Richard Price, John Saville and Klaus Tenfelde, for their helpful comments and suggestions. Only a small proportion of the relevant literature could be cited in the footnotes. I have therefore given preference to noting explicitly comparative studies wherever possible.

' On England see E. P. Thompson, The Making of the English Working Class (New York, 1966); Dorothy Thompson, The Chartists. Popular Politics in the Industrial Revolution (New York, 1984), and especially Iorwerth Prothero, Artisans and Politics in early nineteenth-century London. John Gast and his times (Baton Rouge, 1979). On France see Heinz-Gerhard Haupt, "Frankreich: Langsame Industrialisierung und republikanische Tradition", in Jürgen Kocka (ed.), Europäische Arbeiterbewegungen im 19. Jahrhundert. Deutschland, Österreich, England und Frankreich im Vergleich (Göttingen, 1983), pp. 39-76; William H. Sewell, "Artisans, Factory Workers, and the Forma-
} 
course, true of a number of countries not being dealt with here. Since this social composition and, especially, the artisanal experiences in a limited number of trades correspond to a common orientation of early labour movements on the programmatic level, one may talk of an artisanal phase of the labour movement. This phase began as early as the late eighteenth century in England, and around the 1820s and 1830s in France, Germany and the US, although in the cases of France and the United States the revolutions of the late eighteenth century also had a formative impact. It lasted approximately until the end of the Chartist movement in England, until the Commune of 1871 in France, until the anti-socialist laws in Germany, and until the outbreak of the Civil War in the United States. Since these rather provisional dates only define the temporal scope for a comparative analysis and will have to be reconsidered at the end of it, there is no need to discuss them further. One may well argue, for example, that the 1870 s in Germany as well as the 1840 s and 1850 s in the United States already constitute a kind of transitory stage in many respects. ${ }^{2}$ On the other hand the somewhat arbitrary endpoints of the artisanal phases of four national labour movements should by no means be taken to indicate the end of artisanal influences within the respective organizations. But around the years proposed, urban artisans ceased to constitute the majority of those organized, and artisanal demands began to lose their dominance on the programmatic level too.

This article presents a proposal for and an extremely brief sketch of a comparative treatment of class formation in France, England, Germany and the United States for the periods defined above. Despite considerable

tion of the French Working Class, 1789-1848", in Ira Katznelson and Aristide R. Zolberg (eds), Working-Class Formation. Nineteenth-Century Patterns in Western Europe and the United States (Princeton, 1986), pp. 45-70, and Tony Judt, "The French Labour Movement in the Nineteenth Century", in Tony Judt (ed.), Marxism and the French Left. Studies in Labour and Politics in France, 1830-1981 (Oxford, 1986), pp. 24-114. On Germany see Jürgen Kocka, "Problems of Working-Class Formation in Germany: The Early Years, 1800-1875", in Katznelson and Zolberg, Working-Class Formation, pp. 279-351. On the United States see the recent summary by Bruce Laurie, Artisans into Workers. Labor in Nineteenth-Century America (New York, 1989), esp. pp. 47-112.

${ }^{2}$ Particularly in the case of the United States the mid-1840s may be a more appropriate endpoint than the beginning of the Civil War; see, for example, David Montgomery, "Strikes in Nineteenth-Century America", Social Science History, IV (1980), pp. 81104, esp. pp. 86-88, and the fascinating case study by Iver Bernstein, The New York City Draft Riots. Their Significance for American Society and Politics in the Age of the Civil War (New York, 1990), esp. pp. 78-104. Here, as well as in later sections of this article, I have occasionally revised some of my earlier views: cf. Friedrich Lenger, "Die handwerkliche Phase der Arbeiterbewegung in England, Frankreich, Deutschland und den USA - Plädoyer für einen Vergleich”, Geschichte und Gesellschaft, XIII (1987), pp. 232-243. 
differences all four countries can be considered to have been "industrially advanced" comparatively early. In addition, they are probably the ones in which the study of working-class history has made the most advances. This brief sketch is based solely on secondary sources. It is meant as a preliminary attempt to identify some of the determinants of class formation which are in need of a more detailed comparative investigation. Thus its aim is the generation of hypotheses rather than the presentation of well-documented results.

Following these introductory remarks some of the determining factors such as state formation, industrialization and urbanization will be considered. I then describe the economic situation of the major artisanal trades, and there follows a discussion of the role of artisanal and corporate traditions, as well as of the social relations between masters and men. These paragraphs lay the groundwork for a brief comparative treatment of artisanal politics and organizations in the period dealt with. Finally, some of the strengths, weaknesses and limits of the specific comparative approach advocated in this article are addressed and some of its implications for future work spelled out.

\section{State formation, industrialization and urbanization}

State formation, industrialization and urbanization were certainly some of the most important factors determining the formation of labour movements. Only a few brief remarks are possible here. While both eighteenthcentury England and France had already existed as nation states for a long time, Germany and the United States only became nation states towards the end of the periods considered here, if one accepts the end of the Civil War as marking the final completion of the process in the American case. As far as the degree of what has been called stateness is concerned, however, the continental European countries, with their bureaucratic tradition, had certainly "more state" than their Anglo-American counterparts, although this impression may at least partly result from the negligence of the local level in the English case. ${ }^{3}$ The French or German authorities, for example, intervened much more often and much more directly in the lives of journeymen, etc. The more limited stateness of both centralized England

${ }^{3}$ On stateness (J. P. Nettl) see the brief remarks by Aristide R. Zolberg, "How many exceptionalisms?", in Katznelson and Zolberg, Working-Class Formation, pp. 397-455, esp. pp. 447-448, and more generally the survey by Raymond Grew, "The NineteenthCentury European State", in Charles Bright and Susan Harding (eds), Statemaking and Social Movements. Essays in History and Theory (Ann Arbor, 1984), pp. 83-120, and the contributions to Raymond Grew (ed.), Crises of Political Development in Europe and the United States (Princeton, 1978). 
and federal America was accompanied by different degrees of potential participation. While the United States saw the introduction of universal suffrage for white males as early as the 1820 s it was not until 1918 that extensions to the right to vote resulted in universal male suffrage in England. In comparison both France and Germany introduced universal male suffrage rather early on (in 1848 and 1867-1871 respectively). Again, opportunities to participate in the political process were not necessarily limited to national elections, and artisanal influences on municipal politics would have to be included in any more elaborate comparative analysis. ${ }^{4}$ Still more important in determining workers' attitudes towards the state than the right to vote may have been the part played by state repression. Although the repeatedly extremely bloody interventions of the French state may stand out, a truly comparative evaluation seems as yet impossible. But the state did not only have coercive functions, and its legal structures certainly influenced the formation of the various working classes to a considerable extent as well. The law defined the relationship between employer and worker in important ways, and the scope for union organization and political activities. ${ }^{5}$ Since these questions are just beginning to be explored for the countries being dealt with here, comparative judgements must await further research.

The early labour movements were above all urban phenomena. Since many early factory workers did not live in the larger cities this urban concentration of labour activists suggests that the artisanal dominance was even stronger than the occupational structure alone would suggest. The degree of urbanization thus to a considerable extent set the limits of potential growth for the organizations of the early labour movement. Only in England (and Wales) did most of the population live in towns by the mid nineteenth century; in the United States the corresponding figure was less than twenty per cent. In France and in Prussia about every third inhabitant was an urban dweller by the early 1870 s. Urban growth was by no means a

${ }^{4}$ For an Anglo-German comparison that does include these aspects see John Breuilly, "Civil Society and the Labour Movement, Class Relations and the Law. A Comparison between Germany and England", in Jürgen Kocka (ed.), Arbeiter und Bürger im 19. Jahrhundert. Varianten ihres Verhältnisses im europäischen Vergleich (Munich, 1986), pp. 287-318.

5 See Breuilly, "Civil Society", on the legal structure and political culture; on the repressive role of the state see Heinz-Gerhard Haupt, "Staatliche Bürokratie und Arbeiterbewegung und Arbeiterklasse in Deutschland und Frankreich zwischen 1848 und 1880", in Kocka, Arbeiter, pp. 219-254 (and the comments by Klaus Tenfelde, ibid., pp. 255-260, esp. pp. 259-260), and Ira Katznelson, "Working-Class Formation and the State: Nineteenth-Century England in American Perspective", in Peter B. Evans et al. (eds), Bringing the State Back in (Cambridge, 1985), pp. 257-284. Important on the coercive capacities of the British state is John Saville, 1848. The British state and the Chartist movement (Cambridge, 1987). 
uniform process, however. None of the countries under consideration had growth rates comparable with the United States, where New York City alone had ten times as many inhabitants by 1850 as in $1800 .^{6}$ In France, on the contrary, the unusually slow population growth strongly influenced both the urbanization and industrialization processes. ${ }^{\text {? }}$

For the general position of the urban crafts the development of an urban system and the integration of national markets was similarly important. Again there were marked differences. In Germany a considerable number of smaller centres competed with Berlin, but with the customs union and especially with the rapid extension of the railroad system during the third quarter of the nineteenth century something like a national market emerged. At the same time Paris was only loosely connected with the provincial centres, and transport remained difficult. ${ }^{8}$

Nevertheless, there were sectors of the textile industry producing for world markets. A similar contrast existed between the seaport cities of the United States and some rather isolated towns at the frontier, but the transport revolution ensured that such contrasts were shortlived, at least in the Northern states. Still, it was clearly England where the integration of the national market was most highly developed and the degree of selfsufficiency the lowest during the first half of the nineteenth century.

Furthermore, it was only in England that the non-agrarian sector of the economy determined the occupational structure of the population in the middle of the nineteenth century. ${ }^{9}$ But even in England the typical nonagrarian worker laboured in a workshop rather than a factory. ${ }^{10}$ Tailoring, including dressmaking, as well as construction each employed half a million

${ }^{6}$ See Adna Ferrin Weber, The Growth of Cities in the Nineteenth Century. A Study in Statistics (Ithaca, 1963, first published in 1899), Historical Statistics of the United States. Colonial Times to 1970 (Washington, D.C., 1975), Part 1; B. R. Mitchell, European Historical Statistics 1750-1975 (New York, 1981), and on developments in America, which were very different in the North and the South, Gary B. Nash, "The Social Evolution of Preindustrial American Cities, 1700-1820. Reflections and New Directions", Journal of Urban History, XII (1987), pp. 115-145.

${ }^{7}$ See for example the re-evaluation by Patrick O'Brien and Caglar Keyder, Economic Growth in Britain and France 1780-1914. Two Paths to the Twentieth Century (London, 1978), and the more recent study of Heinz-Gerhard Haupt, Sozialgeschichte Frankreichs seit 1789 (Frankfurt, 1989), esp. pp. 80-114. See also the brief remarks on French urbanization by John M. Merriman, "Introduction: Images of the nineteenth century French city", in John M. Merriman (ed.), French Cities in the Nineteenth Century (London, 1982), pp. 11-41.

${ }^{8}$ This is stressed by Roger Price, An Economic History of Modern France, 1730-1914 (London, 1981), ch. 1.

${ }^{9}$ See Mitchell, European Historical Statistics, pp. 161-173, and U.S. Department of Commerce, Long Term Economic Growth, 1860-1970 (Washington, D.C., 1973), p. 101.

${ }^{10}$ See particularly Raphael Samuel, "Workshop of the World: Steam Power and Hand Technology in mid-Victorian Britain", History Workshop Journal, III (1977), pp. 6-72. 
people in 1851 , shoemaking a further 250,000 . In France male construction workers outnumbered those employed by the textile industries in the early 1860 s. In Germany too clothing and shoemaking employed the highest proportion of those engaged in crafts and industries in the mid-1870s. ${ }^{11}$ Even at the end of the various periods here considered, masons and carpenters, tailors and shoemakers determined the occupational structure of England, France, Germany and the US, especially, of course, in the cities.

\section{The urban trades}

If we take a closer look at the urban crafts we can distinguish at least three groups: besides the building and the food trades, tailoring, shoemaking and cabinet-making always played a dominant role. The building trade is an especially interesting case because there were hardly any technical changes in this trade and it maintained its artisanal character throughout the nineteenth century. Still, there were important differences among the countries dealt with. On the one hand firms varied considerably in size. English and American masons and carpenters typically worked in far larger establishments than their German or French counterparts, although differences between particular towns within Germany or France may have been much greater than those between national averages. ${ }^{12}$ On the other hand there were important differences in the pattern of recruiting workers. In France as well as in Germany a considerable part of the labour force did not live in or near the towns where they worked. As migratory workers - mostly unmarried and not seldom attached to clandestine organizations - they often viewed their interests as being separate from and opposed to those of the resident workers. ${ }^{13}$ Conflicts of this kind played a much lesser role in

${ }^{11}$ See Phyllis Deane, The First Industrial Revolution (Cambridge, 1965); Judt, "The French Labour Movement in the Nineteenth Century", p. 31, and Gerd Hohorst et al., Sozialgeschichtliches Arbeitsbuch. Materialien zur Statistik des Kaiserreichs (Munich, 1975), p. 76.

12 On England see Peter J. Aspinall, "The Internal Structure of the Housebuilding Industry in Nineteenth-Century Cities", in James H. Johnson and Colin G. Pooley (eds), The Structure of Nineteenth-Century Cities (London, 1982), pp. 75-105, esp. p. 77. On Germany see Friedrich Lenger, Sozialgeschichte der deutschen Handwerker seit 1800 (Frankfurt, 1988), pp. 56-57, 97-98. On France see Gabriel Désert, "Aperçus sur l'industrie français du batiment au $X I X^{e}$ siècle", in Jean Pierre Bardet et al., Le Batiment. Enquête sur l'histoire économique $X I V-X I X^{e}$ siècles, vol. 1 (Paris, 1971), pp. 33-120, esp. p. 84. On the United States see for example Bruce Laurie, Working People of Philadelphia, 1800-1850 (Philadelphia, 1980), p. 14.

13 On France see Désert, "Aperçus sur l'industrie français", and Martin Nadaud, Mémoires de Léonard, ancien garçon maçon (Paris, 1976, first published in 1895); on Germany see Wolfgang Renzsch, Handwerker und Lohnarbeiter in der frühen Arbeiter- 
English and North American cities, where the artisans of the building trade were on the whole far more successful in influencing access to the trade. ${ }^{14}$

If we turn to the food trades we encounter much smaller firms, but a similar stability in the production process itself. Two out of three journeymen in the food trades in mid-nineteenth-century Philadelphia toiled in workshops which had fewer than five employees, while in Berlin the average baker employed three or four, the average butcher less than two journeymen or apprentices. In smaller towns like Düsseldorf the typical workshop was still smaller. ${ }^{15}$ Bread factories for example played only a negligible role during the period dealt with here. But while the economic well-being of the smaller masters seems to have varied considerably, the position of the journeymen was rather similar in Berlin or Paris, in Philadelphia or London. Ernst Engelberg, referring to the German case, speaks of the "threefold yoke of low wages, excessive hours and living in the master's household", while Ian McKay characterizes the English situation as "bondage in the bakehouse". ${ }^{16}$ Working conditions go a long way to explaining

bewegung. Zur sozialen Basis von Gewerkschaften und Sozialdemokratie im Reichsgründungsjahrzehnt (Göttingen, 1980), and Arno Herzig, "Kontinuität und Wandel der politischen und sozialen Vorstellungen Hamburger Handwerker 1790-1870", in Ulrich Engelhardt (ed.), Handwerker in der Industrialisierung. Lage, Kultur und Politik vom späten 18. bis ins frühe 20. Jahrhundert (Stuttgart, 1984), pp. 294-319.

${ }_{14}$ For the case of England see Richard Price, Masters, Unions and Men. Work Control in Building and the Rise of Labour 1830-1914 (Cambridge, 1980), and for the United States the case study by Susan E. Hirsch, Roots of the American Working Class. The Industrialization of Crafts in Newark, 1800-1860 (Philadelphia, 1978).

is See for example Laurie, Working People, p. 14; Jürgen Bergmann, Das Berliner Handwerk in den Frühphasen der Industrialisierung (Berlin, 1973), p. 160, and Friedrich Lenger, Zwischen Kleinbürgertum und Proletariat, Studien zur Sozialgeschichte der Düsseldorfer Handwerker 1816-1878 (Göttingen, 1986), pp. 42-46. An interesting case study of butchers is that by John M. Merriman, "Incident at the Statue of the Virgin Mary. The Conflict of Old and New in Nineteenth-Century Limoges", in John M. Merriman (ed.), Consciousness and Class Experience in Nineteenth-Century Europe (New York, 1979), pp. 129-148. He has presented his ideas more fully in The Red City. Limoges and the French Nineteenth Century (New York, 1985).

${ }^{16}$ Ernst Engelberg, "Zur Forschung über Entstehung, Struktur und Entwicklung des Proletariats", in Hartmut Zwahr (ed.), Die Konstituierung der deutschen Arbeiterklasse von den dreißiger bis zu den siebziger Jahren des 19. Jahrhunderts (Berlin, 1981), pp. 247-257, esp. the quote on pp. 255-256. Ian McKay, "Bondage in the Bakehouse? The Strange Case of the Journeymen Bakers, 1840-1880", in Royden Harrison and Jonathan Zeitlin (eds), Divisions of Labour. Skilled Workers and Technological Change in Nineteenth Century England (Brighton, 1985), pp. 47-86, points to the ruinous competition between small masters in London, a situation quite different from other towns where bakers as well as butchers were regularly to be found among the wealthier artisans. Cf. the French examples in Maurice Garden, "The Urban Trades: Social Analysis and Representation", in Steven L. Kaplan and Cynthia J. Koepp (eds), Work in France. Representations, Meaning, Organization, and Practice (Ithaca, 1986), pp. 287-296, and for a sample of German towns see Lenger, Sozialgeschichte der deutschen Handwerker, pp. 52, 93-94, and 102-103. 
why the journeymen of the food trades - occasional strikes notwithstanding - are notoriously absent from the early organizations of the labour movement.

The opposite is true of tailors, shoemakers and cabinet-makers. Not only were these the most numerous trades in most nineteenth-century cities, they also were the best represented in the organizations of the early labour movement. Although differing in many respects, these trades shared a central feature in all of the countries considered here. By the middle of the nineteenth century the traditional structure of the artisanal economy in these trades was to a high degree eroded. Fewer and fewer journeymen worked for small masters engaged in quality work, while more and more artisans became dependent upon merchant capitalists organizing different versions of a putting out system that above all turned out ready-made products. With the small independent master withering away, the traditional distinction between masters and men lost all its former significance: both increasingly shared the status of an outworker without any direct access to the market. As Marx put it succinctly: "Er kauft ihre Arbeit und nimmt ihnen das Eigentum erst am Produkt, bald auch am Instrument, oder er läßt es ihnen als Scheineigentum, um seine eignen Produktionskosten zu vermindern." 17 Again, technical changes played a very limited role. The division of labour progressed nevertheless. In shoemaking and tailoring the cutting of the material became the preserve of a highly-skilled group of specialists, while other stages in the production process were given over to other specialized workers. Thus the waistmaker replaced the tailor, the chair-maker the cabinet-maker and so forth. Specialization, of course, meant dequalification for all but a few journeymen, and was followed by the entrance of unskilled labour into the trades.

There were important differences between the trades as well as between the countries under consideration, however. As is well known from the contemporary observations of Henry Mayhew on London, the excellent work of Christopher Johnson and Joan Scott on Paris, and more recently the studies on New York by Christine Stansell and Sean Wilentz, tailoring fell prey to conditions of sweated labour both earlier and to a greater extent than shoemaking or cabinet-making. It was in tailoring that a complex system of subcontracting was most fully developed that completely blurred the line between wage work and self-employment. ${ }^{18}$ Especially in cabinet-

${ }^{17}$ Karl Marx, Grundrisse der Kritik der Politischen Ökonomie (Berlin, 1974), p. 410.

18 On London see E. P. Thompson and Eileen Yeo (eds), The Unknown Mayhew. Selections from the Morning Chronical 1849-50 (Harmondsworth, 1973), and particularly Barbara Taylor, "'The Men are as bad as their Masters . . .': Socialism, Feminism, and Sexual Antagonism in the London Tailoring Trade in the Early 1830s", Feminist Studies, V (1979), pp. 7-40. On Paris see Christopher H. Johnson, "Economic Change and Artisan Discontent: The Tailors' History, 1800-1848", in Roger Price (ed.), Revolu- 
making, the so-called "honourable" part of the trade resisted somewhat more successfully, while on the other hand centralized production played a considerable role rather early on. Factory production became important in shoemaking during the third quarter of the nineteenth century, but until then the putting out system prevailed. Still, female labour played a much lesser role than in tailoring. These differences between the trades are remarkably similar in all our four countries.

Much more difficult to measure are national differences in time and degree, and my following impressions - it needs to be stressed - therefore remain rather preliminary. The putting out system in the above-mentioned urban trades occurred far earlier in England than in the United States or in continental Europe. Eric Hobsbawm has repeatedly noted the virtual absence of the small commodity producer in nineteenth-century England, and Christiane Eisenberg has more recently demonstrated for tailoring that the proletarianization of artisans began much earlier in England and then proceeded far more slowly than in any of the other countries under consideration here. ${ }^{19}$ By the middle of the nineteenth century the United States may have come closest to replicating English conditions as far as the putting out system is concerned. Although its beginnings in the late eighteenth century were limited and rather late, the erosion of the traditional artisanal economy seems to have proceeded especially quickly. While the War of 1812 brought a stronger impulse towards the putting out system in towns like Baltimore, Philadelphia or New York, in some trades and places the mid nineteenth century had already witnessed a partial decline in outwork in the urban trades. ${ }^{20}$ If dispersed impressions from shoemaking in Lynn, Massachusetts, or cabinet-making in Cincinnati, Ohio, are at all repre-

tion and Reaction. 1848 and the Second French Republic (London, 1975), pp. 87-114, and Joan W. Scott, "Men and Women in the Parisian Garment Trades: Discussions of Family and Work in the 1830s and 1840s", in Pat Thane et al. (eds), The Power of the Past. Essays for Eric Hobsbawm (Cambridge, 1984), pp. 67-93. On New York see Christine Stansell, City of Women, Sex and Class in New York, 1789-1860 (Urbana, 1987), and Sean Wilentz, Chants Democratic. New York City \& the Rise of the American Working Class, 1788-1850 (New York, 1986).

${ }^{19}$ See for example Eric Hobsbawm, "The Making of the Working Class 1870-1914", in Eric Hobsbawm, Workers: Worlds of Labor (New York, 1984), pp. 194-213, esp. p. 195; Christiane Eisenberg, Deutsche und englische Gewerkschaften: Entstehung und Entwicklung bis 1878 im Vergleich (Göttingen, 1986), esp. pp. 30-43. See also on early eighteenth-century shoemaking the example given by John Rule, "The property of skill in the period of manufacture", in Patrick Joyce (ed.), The historical meanings of work (Cambridge, 1987), pp. 99-118, esp. p. 101.

${ }^{20}$ On Baltimore see Charies G. Steffen, The Mechanics of Baltimore. Workers and Politics in the Age of Revolution, 1763-1812 (Urbana, 1984), esp. pp. 44-45; on Philadelphia see Laurie, Working People, ch. 1; on New York see Wilentz, Chants Democratic, pp. 108-129, and for a study of developments in general see Laurie, Artisans into People, ch. 1 . 
sentative, then these trades, with the notable exception of the clothing industry, displayed rather strong tendencies towards centralized production even before the Civil War. ${ }^{21}$ In contrast to the United States, where comparatively high wages may have accelerated the tendency towards centralized production and towards the replacement of skilled by unskilled labour, the erosion of independent commodity production began earlier in continental Europe, but its expansion took place at a slower pace. At the end of the eighteenth century the putting out system had already been well-established in tailoring or shoemaking in towns like Augsburg, Berlin or Paris, but there were few signs of its decline before the $1870 \mathrm{~s} .{ }^{22}$ Whatever differences there were in the development of tailoring, shoemaking and cabinet-making between England, France, Germany and the US from the eighteenth century on, one characteristic needs to be stressed: there was a remarkable structural similarity in the 1830 s and $1840 \mathrm{~s}$. At that time the putting out system dominated these mass trades in places as different as Paris and London, Berlin and Philadelphia, New York and Düsseldorf, and Cincinnati and Toulouse. ${ }^{23}$

\section{Artisanal culture and the corporate past}

Although the urban trades in our four countries show a remarkable similarity in the broad outlines of their economic development towards the middle of the nineteenth century, some fundamental differences regarding the legal situation and the content and role of corporate traditions must not be overlooked. While both England and the United States were practically free of any guild regulations in the period under consideration, things were different in continental Europe. Although corporate restrictions were abolished in France with the Great Revolution, corporate traditions stayed very much alive during the first half of the nineteenth century, as William Sewell's brilliant work has shown. ${ }^{24}$ The compagnonnages were never more

${ }^{21}$ On Lynn see Alan Dawley, Class and Community. The Industrial Revolution in Lynn (Cambridge, MA, 1976), and on Cincinnati Steven J. Ross, Workers on the edge. Work, Leisure, and Politics in industrializing Cincinnati, 1788-1890 (New York, 1985).

22 On Augsburg see Roland Bettger, Das Handwerk in Augsburg beim Übergang der Stadt an das Königreich Bayern (Augsburg, 1979); on Berlin see Bergmann, Das Berliner Handwerk; and on Paris see Johnson, "Economic Change and Artisan Discontent".

${ }^{23}$ See the case studies cited in notes 18, 21, and 22, and also Ronald Aminzade, "Reinterpreting capitalist industrialization: a study of nineteenth century France", Social History, IX (1984), pp. 329-350, esp. pp. 344-346 on Toulouse, and Friedrich Lenger, "Polarisierung und Verlag: Schuhmacher, Schneider und Schreiner in Düsseldorf 1816-1861", in Engelhardt, Handwerker in der Industrialisierung, pp. 127-145, on Düsseldorf.

${ }^{24}$ William $\mathrm{H}$. Sewell, Work and Revolution in France. The language of labor from the old regime to 1848 (Cambridge, 1980). 
popular among French journeymen than during the first half of the nineteenth century. ${ }^{25}$ Guild regulations were still in force to some degree in some German states well into the $1860 \mathrm{~s}$, and a number of specific features of the guild tradition remained: unmarried journeymen could still be found in the early twentieth century. ${ }^{26}$ In comparative perspective there emerges an Anglo-American and a continental European pattern when the role of the corporate past is examined. As Eric Hobsbawm has noted, "the core of German or French journeymen collectivity was to be found outside the workshop - in the institutionalized period of travel, the journeymen's hostel or lodging house where the rituals of initiation took place". In England, on the other hand, "the essential locus of the British apprentice's socialization into the ways of the journeyman was patently the workplace". ${ }^{27}$ These clear distinctions, with their obvious relevance for the formation of labour movements should not lead us to overlook important Anglo-American and French-German differences however. On the one hand it seems highly unlikely that given the rather rapid erosion of the apprenticeship system in the United States, what Christiane Eisenberg has called the clandestine curriculum of the English journeyman could be equally well-enforced on the American shop floor ${ }^{28}$ On the other hand French-German differences stand out even more clearly. Above all, tramping, hardly known in the US, had never been obligatory in France (or

${ }^{25}$ See Alain Faure's introduction, "A propos de Perdiguier: qu'est-ce que le compagnonnage?", to the informative autobiography of Agricole Perdiguier, Mémoires d'un compagnon (Paris, 1982), pp. 7-33. See also Steven Kaplan, "Réflexions sur la police du monde du travail, 1700-1815”, Revue historique, CCLXI (1979), pp. 17-77, and Cynthia M. Truant, "Solidarity and Symbolism among Journeymen Artisans: The Case of Compagnonnage", Comparative Studies of Society and History, XXI (1979), pp. 214 226. Emile Coornaert's Les compagnonnages en France du moyen age à nos jours (Paris, 1966) is a disappointing study.

${ }^{26}$ A good recent survey of the repeal of guild regulations in the German states is Harald Steindl, "Die Einführung der Gewerbefreiheit", in Helmut Coing (ed.), Handbuch der Quellen und Literatur der neueren europäischen Privatrechtsgeschichte, vol. 3, Part 3 (Munich, 1986), pp. 3529-3628. On the role of the unmarried journeymen in earlytwentieth-century Germany see Josef Ehmer, "Das Heiratsverhalten und die Traditionen des Kapitalismus. England und Mitteleuropa im 19. Jahrhundert" (forthcoming, Göttingen, 1991).

${ }^{27}$ Eric Hobsbawm, "Artisans and Labour Aristocrats?', in Hobsbawm, Workers, pp. 252-272, and especially p. 259.

${ }^{28}$ On the United States see W.J. Rorabaugh, The Craft Apprentice. From Franklin to the Machine Age (New York, 1986), although the unstructuredness of the book makes it somewhat difficult to draw conclusions from the material presented. On the clandestine curriculum see Eisenberg, Deutsche und englische Gewerkschaften, pp. 67-72, and particularly Clive Behagg, "Secrecy, ritual and folk violence: the opacity of the workplace in the first half of the nineteenth century", in Robert D. Storch (ed.), Popular Culture and Custom in Nineteenth Century England (London, 1982), pp. 154-179. 
England) as it has been in many German trades. ${ }^{29}$ And although in both countries the state had clearly taken sides with the masters against the journeymen in attempts to reform the eighteenth-century guilds, journeymen organizations were much more successfully suppressed in Germany during the first half of the nineteenth century. ${ }^{30}$ Thus it is only in France that we find the almost uninterrupted existence of the clandestine confraternités and compagnonnages from the eighteenth until well into the nineteenth century. ${ }^{31}$

A similar dichotomy between an Anglo-American and a continental European pattern emerges from an analysis of the respective languages of labour. The traditional distinction between Meister and Geselle, between maitre, patron, and increasingly bourgeois and compagnon or ouvrier maintained its significance after the abolition of the guild system. The term Handwerker in German became more and more restricted to the selfemployed master artisan. ${ }^{32}$ In general, the German and French terminology, with its strong corporative connotations, stressed class distinctions even where they had been completely eroded, as they were in some of the urban trades portrayed above. The English artisan or craftsman as well as the American mechanic denoted the skilled worker and included at least the smaller masters. But again Anglo-American differences need to be taken seriously. While the English artisan, although encompassing small masters, was clearly distinguished from manufacturers and larger employers, the American mechanic was less sharply defined. ${ }^{33}$

Still, the linguistic point should not be overdrawn. Neither did the term "mechanic", which was not specific to any one class, prevent the journey-

${ }^{29}$ See Ulrich-Christian Pallach, "Fonctions de la mobilité artisanale et ouvrière - compagnons, ouvriers et manufacturiers en France et aux Allemagnes $\left(17^{e}-19^{e}\right.$ siècles), Première partie: De la fin du $17^{\mathrm{e}}$ siècle au début de l'époque révolutionnaire en $1789^{\prime \prime}$. Francia, XI (1983), pp. 365-406. Although not being obligatory tramping seems to have been very common in France: see Michael Sonenscher, "Journeymen's Migrations and Workshop Organization in Eighteenth-Century France", in Kaplan and Koepp, Work in France, pp. 74-96.

${ }^{30}$ See Kaplan, "Réflexions", on France, and Lenger, Sozialgeschichte der deutschen Handwerker, pp. 16-18 and 63-64, on Germany.

${ }^{31}$ This is demonstrated in Sewell, Artisans, esp. p. 58. See also David Garrioch and Michael Sonenscher, "Compagnonnages, Confraternities and Associations of Journeymen in Eighteenth-century Paris", European History Quarterly, XVI (1986), pp. 25-45, on the differences between and the regional distribution of those alternative forms of organization.

32 See Jürgen Kocka, "Craft Traditions and the Labour Movement in NineteenthCentury Germany", in Thane et al., The Power of the Past, pp. 95-117.

${ }_{33}$ With regard to the language of class in England see, for example, Eric Hobsbawm, "Soziale Ungleichheit und Klassenstrukturen in England: Die Arbeiterklasse", in HansUlrich Wehler (ed.), Klassen in der europäischen Sozialgeschichte (Göttingen, 1979), pp. 53-65. 
men in New York or Lynn, Massachusetts, from recognizing that their interests were opposed to those of their employers; nor did the stress on distinction between maitre, and compagnon, Meister and Geselle lead necessarily to separate social spheres. ${ }^{34}$ As Agulhon has shown for France, sociability often united both masters and men in a common artisanal culture; and a recent case study of Düsseldorf suggests a similar phenomenon occurred there too. ${ }^{35}$

A prerequisite for the formation of such an artisanal culture was the existence of a larger proportion of married journeymen of course. While it is well known that the unmarried journeyman was uncommon in Britain, the picture is rather more complicated for both Germany and the United States. While the marriage of journeymen was rather common in some trades and places by the mid nineteenth century, there were also cities where, during the German revolution of 1848 , journeymen were still fighting for the right to live on their own. ${ }^{36}$ The situation in eighteenth-century France had been similarly tense. ${ }^{37}$ In the United States journeymen had all but ceased to live in the master's household in the post-revolutionary seaport cities, but this phenomenon of living in was still to be found in smaller places in the West two generations later.$^{38}$ Similar differences hold true for the distribution of wealth, patterns of residential segregation, etc.

34 See Wilentz, Chants Democratic, on New York, and Dawley, Class and Community, on Lynn; on the latter town see also Paul G. Faler, Mechanics and Manufacturers in the Early Industrial Revolution. Lynn, Massachusetts, 1780-1860 (Albany, 1981), Friedrich Lenger, "Class, culture and class consciousness in antebellum Lynn: a critique of Alan Dawley and Paul Faler", Social History, VI (1981), pp. 317-332, and Mary H. Blewett, "Work, Gender and the Artisan Tradition in New England Shoemaking, 1780-1860", Journal of Social History, XXVII (1983/84), pp. 221-248.

${ }^{35}$ See Maurice Agulhon, "Working Class and Sociability in France before 1848", in Thane et al., The Power of the Past, pp. 37-66, and Lenger, Zwischen Kleinbürgertum und Proletariat. Cf. from a somewhat different angle Christiane Eisenberg, "Arbeiter, Bürger und der 'bürgerliche Verein' 1820-1870. Deutschland und England im Vergleich", in Jürgen Kocka (ed.), Bürgertum im 19. Jahrhundert.Deutschland in europäischen Vergleich, vol. 2 (Munich, 1988), pp. 187-219.

${ }^{36}$ See for example Lenger, Zwischen Kleinbürgertum und Proletariat, pp. 117-127, on Düsseldorf and Hartmut Zwahr, Zur Konstituierung des Proletariats als Klasse. Strukturuntersuchung über das Leipziger Proletariat während der industriellen Revolution (Berlin, 1978), p. 60, on Leipzig.

37 See for example Cynthia Truant, "Independent and Insolent: Journeymen and Their 'Rites' in the Old Regime Workplace", in Kaplan and Koepp, Work in France, pp. 131-173, esp. 134.

${ }^{38}$ On New York see Howard B. Rock, Artisans of the New Republic: The Tradesmen of New York City in the Age of Jefferson (New York, 1979), and Wilentz, Chants Democratic, esp. p. 49. On Philadelphia see Sharon V. Salinger, "Artisans, Journeymen, and the Transformation of Labor in Late Eighteenth-Century Philadelphia", William and Mary Quarterly, XL (1983), pp. 62-84, esp. p. 64, and on Rochester see Paul E. Johnson, A Shopkeeper's Millennium. Society and Revivals in Rochester. New York 1815-1837 (New York, 1978), p. 46. 
Here again cities like Philadelphia or New York were characterized by rather rigid distinctions within trades as early as the early nineteenth century, while smaller towns, especially those near the frontier, still experienced more harmonious class relations..$^{39}$ On the whole, the present state of research does not allow us to make a precise comparative evaluation of the many facets of the relations between masters and men however.

\section{Early labour movements}

When we turn to the formation of the early labour movement certain correspondences between the Anglo-American and the continental European traditions and the character and strength of trade unions in these countries become apparent. In England trade unions developed closely resembling guildlike organizations as early as the early-modern period. ${ }^{40}$ Characterized by a clear-cut separation of single crafts and the development of an extensive system of support - often grown out of friendly societies - this organizational model proved very successful in controlling the labour market, in defending the apprenticeship system and, last but not least, in influencing working conditions on the shop floor. The early American unions - founded at the turn of the nineteenth century - adopted the English model, but attempts to build up organizations transcending craft boundaries were made comparatively earlier. ${ }^{41}$ Especially when immigration increased drastically in the 1840 s and 1850 s the successful defence of apprenticeship rules could take on a new meaning, however, when it led to the exclusion of foreigners. ${ }^{42}$

The strict observance of craft boundaries was also typical of the German journeymen brotherhoods or the French compagnonnages. But these traditions did not foster the formation of trade unions directly. Besides the

${ }^{39}$ On New York see Rock, Artisans of the New Republic, and Wilentz, Chants Democratic. On Philadelphia see Laurie, Working People of Philadelphia, on Cincinnati see Ross, Workers on the edge, and on Albany see Brian Greenberg, Worker and Community. Response to Industrialization in a Nineteenth-Century American City, Albany, New York, 1850-1884 (Albany, 1985).

${ }^{40}$ R. A. Leeson, Travelling Brothers. The six centuries' road from craft fellowship to trade unionism (London, 1979), and C. R. Dobson, Masters and Journeymen. A Prehistory of Industrial Relations, 1717-1800 (London, 1980).

41 In addition to the local studies of Rock, Wilentz, and Laurie cited in note 39 see also Leonard Bernstein, "The Working People of Philadelphia from Colonial Times to the General Strike of 1835", Pennsylvania Magazine of History and Biography, LXXIV (1950), pp. 322-339, and Salinger, "Artisans, Journeymen, and the Transformation of Labor".

${ }^{42}$ See Hirsch, Roots of the American Working Class, p. 48. The obviously important strength of nativism within the American working class in this period is one of the many aspects neglected in this paper. 
considerable pressure from both French and German authorities and the lessened importance of the workplace for working-class life, the numerous internal divisions among the journeymen played a major role. ${ }^{43}$ Unmarried, migrant journeymen often found themselves in conflict with their married and resident colleagues, while the fights between the members of the different compagnonnages were famous for their violence. These splits made both strikes and organization more difficult, without necessarily diminishing the readiness for conflict. Again, the dichotomy between an Anglo-American and a French-German pattern must not be overdrawn. In comparison with their English and American counterparts both French and German unions were weak. But while French artisans had some kind of corporate workers' organization in all major cities, their German colleagues remained with almost no form of organization during most of the first half of the nineteenth century. ${ }^{44}$ At least the German mutual aid societies, about which we still know far too little, seem to have been less directly linked to both political and union organizations. ${ }^{45}$ At the same time it may well have been the weakness of exclusive craft union organization on the Continent that eased the emergence of class solidarities which transcended traditional craft boundaries. ${ }^{46}$

Despite all the national peculiarities, some common features stand out clearly as well. In all our four countries shoemakers, tailors, and cabinetmakers were especially prominent in attempts to establish organizations which spanned craft boundaries. Two reasons may be adduced to explain this significant characteristic. On the one hand the economic situation in their trades made successful strikes less likely than, for example, in the building trade ${ }^{47}$ Unions were correspondingly often weaker than in other

${ }^{43}$ See in addition to the literature already cited Hans-Ulrich Thamer, "Arbeit und Solidarität. Formen und Entwicklungen der Handwerkermentalität im 18. und 19. Jahrhundert in Frankreich und Deutschland", in Engelhardt, Handwerker in der Industrialisierung, pp. 469-496, and Friedrich Lenger, "Tradizioni artigiane e origini del movimento operaio. Alcune riflessioni sulla recente letteratura tedesca", Movimento operaio e socialista, VIII (1985), pp. 477-485.

${ }_{44}$ See for example Sewell, Artisans, esp. p. 58, and Kocka, Problems, esp. pp. 330-333.

45 Jonathan Sperber, Popular Catholicism in Nineteenth Century Germany (Princeton, 1984), pp. 31-32, has called them the "mass organization of the proletariat, long before the existence of working class parties or cultural organizations", but that does not imply that they were direct precursors of the latter.

46 At least in the French case the parallel between the weakening of the compagnonnages and the emergence of organizational forms overcoming craft boundaries seems well established. See Agulhon, "Working Class and Sociability in France", and the case study by Ronald Aminzade, "The Transformation of Social Solidarities in Nineteenth Century Toulouse", in Merriman, Consciousness and Class, pp. 85-105. On Germany see the interesting case study by Michael J. Neufeld, The Skilled Metalworkers of Nuremberg. Craft and Class in the Industrial Revolution (New Brunswick, 1989).

${ }^{47}$ See for example Prothero, Artisans and Politics, and Laurie, Working People. 
trades. On the other hand one may speculate that the specific pattern of exploitation to which those in the putting out system were subjected made other remedies more attractive.

Tailors, shoemakers and cabinet-makers thus played a decisive role in the early political organizations of the working class. The beginnings of artisanal politics are more difficult to determine. Urban artisans were often prominent among the social protesters of early-modern cities, but selfconscious programmes or organizations hardly appeared before the American and French Revolutions of the late eighteenth century. ${ }^{48}$ The Parisian sansculottes articulated their interests as small commodity producers in clear opposition to the larger retailers and merchants. They not only demanded the establishment of fixed prices, wages and profits, but petitioned: "Que nul ne puisse avoir qu'un atelier, qu'une boutique."

Artisanal participation in the American and French Revolutions of the late eighteenth century established important traditions of artisanal republicanism in both countries that continued to unite masters and men for a considerable period of time. But neither in France nor in the United States did the revolutionary years lead to the beginnings of a continuous period of political activity among artisans and craftsmen. Instead the French Revolution marked the beginning of an artisanal labour movement in England. This may sound paradoxical, but state repression following the French Revolution played a decisive role in giving organizations like the London Corresponding Society more of a class character ${ }^{50}$ The English labour movement during the first half of the nineteenth century, however, diverges markedly from comparable movements in France, Germany or the United States in one central respect: it developed into an alliance of both the urban artisanate and the textile workers of the industrial communities in Lancashire, Yorkshire and Nottinghamshire, mobilizing millions of workers and artisans for the Charter. ${ }^{51}$ Most of those working in the textile

${ }^{48}$ For the United States see Staughton Lynd and Alfred Young, "After Carl Becker: The Mechanics and New York City Politics, 1774-1801. (Introduction)”, Labor History, V (1964), pp. 215-224, and Staughton Lynd, "The Mechanics in New York City Politics, 1774-1788", ibid., pp. 225-246, as well as the brief survey by Alfred F. Young, "Revolutionary Mechanics", in Paul Buhle and Alan Dawley (eds), Working for Democracy. American Workers from the Revolution to the Present (Urbana, 1985), pp. 1-10, and the case study by Steffen, The Mechanics of Baltimore.

49 Address of the "Sans-Culottes" section to the National Convention of 2 September 1793, quoted in Albert Soboul, Les sans-culottes parisiens en l'an II. Mouvement populaire et gouvernement révolutionnaire (1793-1794) (Paris, 1968), p. 70. See also Sewell, Artisans, pp. 100-113, and the more recent critique by Michael Sonenscher, "The sans-culottes of the Year II: rethinking the language of labour in revolutionary France", Social History, IX (1984), pp. 301-328.

${ }^{50}$ See for example Prothero, Artisans and Politics, and particularly Thompson, The Making of the English Working Class.

${ }^{51}$ London probably came closest to having an artisanally dominated movement: see the 
districts were skilled outworkers, thus resembling our urban artisans in many respects. That should not lead us to belittle the achievement of the Chartist movement in uniting two otherwise quite distinct groups within the English working class however. ${ }^{52}$

A comparably powerful working-class movement did not emerge in any of the other countries during the period under consideration here, and space does not permit me to sketch even briefly the development of working-class movements in France, Germany, England or the United States during this period. The enormous disparities between France, with its emerging socialist movement, in the years following the revolution of 1830 , the United States, with its short-lived Workingmen's Parties, and Germany, with its virtual lack of working-class organizations before the revolution of 1848 and its presumably early formation of a socialist working-class party since the $1860 \mathrm{~s}$, are well known. ${ }^{53}$

Instead of charting the development of labour organizations and movements in our four countries, however, I would like to point to the fact that though there were enormous differences between these movements, they all developed rather similar analyses of the early capitalist economy. These analyses corresponded closely to the experiences of the urban artisans confronted with the putting out system and situating exploitation in the sphere of exchange. Although up to now we have focused exclusively on tailors, shoemakers and cabinet-makers, it must be noted that quite a few urban trades were organized along very similar lines. The silk weavers of Lyons come immediately to mind, and other trades like cigar making, and metalworking had similar structures everywhere. ${ }^{54}$ Seen from the perspec-

excellent study by David Goodway, London Chartism 1838-1848 (Cambridge, 1982), and the summary by Dorothy Thompson, The Chartists, esp. part II.

${ }^{52}$ Neither E. P. Thompson in The Making of the English Working Class nor Gareth Stedman Jones in his "Rethinking Chartism", in James Epstein and Dorothy Thompson (eds), The Chartist Experience. Studies in Working Class Radicalism and Culture, 1830 1860 (Basingstoke, 1982), pp. 3-58, succeed in explaining how the Chartists managed to overcome this oppostion.

${ }^{53}$ On France see besides the literature already quoted Bernhard H. Moss, "Parisian Workers and the Origins of Republican Socialism 1830-1833", in John H. Merriman (ed.), 1830 in France (New York, 1975), pp. 203-221, and Bernhard H. Moss, "Parisian Producers' Associations (1830-51): The Socialism of Skilled Workers", in Price, Revolution and Reaction, pp. 73-86, and on the American Workingmen's Parties the brief survey by Franklin Rosement, "Workingmen's Parties", in Dawley and Buhle, Working for Democracy, pp. 11-18.

${ }^{34}$ On Lyonnais silk weaving see for example Robert Bezucha, The Lyon Uprising of 1834: Social and Political Conflict in a Nineteenth-Century City (Cambridge, MA, 1974), and George J. Sheridan, "Household and craft in an industrializing economy: the case of the silkweavers of Lyons", in Merriman, Consciousness and Class. On cigar making see Zwahr, Zur Konstituierung des Proletariats, and on metalworking the case study by Neufeld, The Skilled Metalworkers of Nuremberg. 
tive of the artisans in these trades the capitalist appeared as a middleman, who-unproductive himself - stepped in between the producers and robbed them of part of their wages. As Thomas Hodgskin put it in 1825: "Betwixt him who produces food and him who produces clothing, betwixt him who makes instruments and him who uses them, in steps the capitalist, who neither makes nor uses them and appropriates to himself the produce of both [. . .]". ${ }^{55}$ There is no need to discuss the inherent limitations of this "artisanal class theory", as Gareth Stedman Jones has termed it. ${ }^{56}$ Such an artisanal class theory was developed in all our four countries in very similar ways and reflected directly the experience of urban artisans under the putting out system.

Again, this is not to deny that there were crucially important differences in the respective "languages of class". But whether such an artisanal analysis of early capitalism was rooted in egalitarian notions of American republicanism or in an idealization of Germany's corporate past, whether it was closely connected with the longing for land or not, the basic diagnosis was the same. And so was the cure. Producers' cooperatives were viewed as the means to end the dependency of self-employed artisans on parasitic middlemen. Often founded simply to counter unemployment, producers' associations were by no means necessarily part of far-reaching early socialist schemes. Nor were they everywhere closely linked to the political left. In Germany both liberals and socialists strongly advocated and quite often founded cooperatives in the $1850 \mathrm{~s}$ and $1860 \mathrm{~s} .{ }^{57}$ Still, they always embodied the conviction that one could easily do without capitalists. The most important differences between our four countries concerned the role of the state in connection with the foundation of cooperatives. Despite such fundamental disagreements these producers' cooperatives were the central demand of the early artisanal labour movements around the middle of the nineteenth century. This is not to say that they were equally popular in all of the countries under consideration here. William Sewell noted long ago that "a network of self-governing producers' associations [. . . ] touched deep

${ }_{55}$ Quoted in Thompson, The making of the English Working Class, p. 778.

${ }^{56}$ See Gareth Stedman Jones, "Die Grenzen proletarischer Theoriebildung in England vor 1850", Archiv für die Geschichte des Widerstandes und der Arbeit, I (1980), pp. 79-84, and ibid., IV (1981), pp. 105-123, and Noel W. Thompson's more recent study, The People's Science. The Popular political Economy of Exploitation and Crisis, 18161834 (Cambridge, MA, 1984), which also stresses that the ideas of Hodgskin and others of the 1820 s were not further developed later on. See also Gregory Claeys, Machinery, Money and the Millennium. From Moral Economy to Socialism, 1815-60 (Cambridge, 1987).

57 See Heinz-Gerhard Haupt and Friedrich Lenger, "Liberalismus und Handwerk in Frankreich und Deutschland um die Mitte des 19. Jahrhunderts", in Dieter Langewiesche (ed.), Liberalismus im 19. Jahrhundert. Deutschland im europäischen Vergleich (Göttingen, 1988), pp. 305-331, for a French-German comparison. 
chords of response among men whose traditions and organizational forms included [. . .] important corporate strands". ${ }^{58}$ This may partly explain the greater popularity of producers' associations on the continent. In England, on the other hand, comparable corporate traditions were missing, and the much earlier completion of the proletarianization of the urban crafts may well have diminished the attractiveness of any scheme promising to secure self-employment, be it collectively or otherwise. Defending their "property of skill" - as John Rule has put it - had become more important for many English artisans than owning the means of production. ${ }^{59}$

I want to stress here this common theme which linked early labour movements in their artisanal phase rather than the undeniable differences between them, and I should like to indicate at least a few of the implications this remarkable similarity has. On the one hand the thesis of an artisanal phase questions the notion of one labour movement developing continuously unless interrupted by external interventions, like wars, etc. ${ }^{60}$ At a time when hardly anybody believes in the revolutionary mission of the ("mature") proletariat any longer, a re-evaluation of a labour movement often discredited as petit bourgeois seems overdue. ${ }^{61}$ On the other hand I deem a serious consideration of the artisanal labour movements described in this paper to be worthwhile because the obvious correlation between the rather unelaborate and transparent mode of exploitation and the fundamental radicalism of protest may have implications for our judgement of labour movements in later periods. ${ }^{62}$

${ }^{58}$ William H. Sewell, "Social Change and the Rise of Working-Class Politics in nineteenth-century Marseille", Past and Present, LXV (1974), pp. 75-109. The quote above appears on page 105 .

59 Rule, "The property of skill". This juxtaposition should make clear that my argument does not depend in any way on the notion of skill, which has recently been vigorously criticized by Jacques Rancière, "The Myth of the Artisan. Critical Reflections on a Category of Social History", International Labor and Working Class History, XXIV (1983), pp. 1-16, with nineteenth-century tailors and shoemakers in mind.

${ }^{60}$ But I would insist on treating this artisanal phase as a stage in the formation of a working class. I cannot support those who attempt to interpret it as a populist movement or who separate it categorically from later developments, as Hobsbawm in "The Making of the Working Class" does. On the populist position see Craig Calhoun, The Question of Class Struggle. Social Foundations of Popular Radicalism during the Industrial Revolution (Oxford, 1982); Craig Calhoun, "The Radicalism of Tradition: Community Strength or Venerable Disguise and Borrowed Language?", American Journal of Sociology, LXXXVIII (1983), pp. 886-914; Craig Calhoun, "Industrialization and Social Radicalism. British and French Workers' Movements and the Mid-Nineteenth-Century Crises", Theory and Society, XII (1983), pp. 485-504, and the critical comments by Gareth Stedman Jones, "The mid-century crisis and the 1848 Revolutions", ibid., pp. 506-519.

${ }^{61}$ Such scepticism was of course widespread before the recent developments in Eastern Europe. See for example André Gorz, Adieux au Prolétariat. Au-delà du socialisme (Paris, 1980).

${ }_{62}$ In this respect Marx's distinctions between the appropriation of nature and the 


\section{Conclusion}

Let me finally turn briefly to what I consider to be the main strengths and weaknesses of the comparative approach I propose. The main weakness is obviously that it does not provide an answer to the question why - given all the similarities between the economic and social situations of early labour activists - did the early labour movements in England, France, Germany and the United States follow such divergent paths? This weakness is, however, not a necessary consequence of the approach. But neither is it an accidental feature of an approach that gives priority to class formation over the formation of working-class organizations. On the one hand detailed histories of the four countries' working-class movements could easily be integrated into the comparative framework. Any explanation of these marked differences would have to acknowledge the very different political conditions first. ${ }^{63}$ Whether political democracy was "the nail in the coffin of class consciousness" in the United States, as Alan Dawley has argued, needs to be discussed, as well as the importance of republican-socialist cooperation for class politics in France, the impact of state repression of Chartism, the attitude of German Liberalism towards early labour organization, and numerous other issues. ${ }^{64}$ On the other hand such an expanded and, of course, improved comparative analysis would still face the considerable conceptual problem of satisfactorily linking the different dimensions of the process of class formation. ${ }^{65}$ As it stands my proposal links the

appropriation of the product and between the formal and the real subordination of labour possess considerable explanatory power. For two convincing applications to labour history see Gareth Stedman Jones, "Class Struggle and the Industrial Revolution", in Gareth Stedman Jones, Languages of Class. Studies in English working class history 1832-1982 (Cambridge, 1983), pp. 25-75, and Richard Price, "Structures of subordination in nineteenth-century British industry", in Thane et al., The Power of the Past, pp. 119-142.

${ }_{63}$ There is clearly a consensus emerging on this point. See for example Zolberg, "How many exceptionalisms?", or John Breuilly, "Artisan Economy, Artisan Politics, Artisan Ideology: The Artisan Contribution to the Ninenteenth-Century European Labour Movement", in Clive Emsley and John Walvin (eds), Artisans, Peasants and Proletarians, 1760-1860. Essays presented to Gwynn A. Williams (London, 1985), pp. 187-225. ${ }^{64}$ See Dawley, Class and Community, p. 70. For a far more nuanced and convincing version of this argument cf. Amy Bridges, "Becoming American: The Working Classes in the United States before the Civil War", in Katznelson and Zolberg, Working-Class Formation, pp. 157-196, and her fine case study A City in the Republic: Antebellum New York and the Origins of Machine Politics (Cambridge, 1984).

${ }_{65}$ I do not intend to enter the debate about an appropriate conceptualization of class formation here - see Zwahr, Zur Konstituierung des Proletariats; Kocka, "Problems of Working-Class Formation", and for my own view Lenger, Zwischen Kleinbürgertum und Proletariat - but I cannot see any justification for criticising the Marxian dichotomy of a "class in itself vs. for itself" as rendering "thinking about the links between the social organization of class, class dispositions, and collective action superfluous", as does Ira 
economic, social and political dimensions of the process solely through assuming a rather naïve correspondence between socio-economic experience and political consciousness, without saying much about the form and strengths of organizations or the role and importance of ideological traditions.

This weakness has certain advantages. It directs attention to the complicated process in which shared class experiences were or were not transformed into an awareness of class that may or may not have found expression in a socialist party, a liberal union, or a local mutual aid society. Greater conceptual clarity in these matters would enable us to avoid many of the faulty hypotheses abundant in comparative statements. Thus many answers to Sombart's famous question "Why is there no socialism in the United States?" imply misleading and oversimplified assumptions about the European situation, as does Dawley's argument referred to above. ${ }^{66}$ After all, the American working class does by no means look docile when economic struggles are compared. Even where workers appeared to be both rather class conscious and highly politicized, their organizations may have been locally rather than nationally orientated.

It is because of differences like those noted above that any broader analysis of the formation of labour movements must begin with the comparative analysis of class formation and try to integrate the history of organizations into such a framework. ${ }^{67}$ Otherwise comparative labour history will have to sacrifice whatever progress labour history has achieved during the last twenty-five years. Such a demand is, of course, by no means limited to the artisanal phase of the labour movement. But given the more developed state of research into the social history of the nineteenth-century working class it may be more easily realized than for more recent times. In view of the preliminary results of this survey the role of the state seems the most fruitful starting point for a comparative analysis of the formation of the early labour movements. While the socio-economic situation of urban

Katznelson in "Working-Class Formation: Constructing Cases and Comparisons", in Katznelson and Zolberg, Working-Class Formation, pp. 3-41; the above quotes are taken from p. 20.

${ }^{66}$ Werner Sombart, Warum gibt es in den Vereinigten Staaten keinen Sozialismus? (Tübingen, 1906). See the excellent critique of many of the comparisons implicit in answers to Sombart's question by Eric Foner, "Why is there no Socialism in the United States?", History Workshop Journal, XVII (1984), pp. 57-80.

${ }^{67}$ Only such an integrated approach promises to yield results that constitute a significant advance on earlier typologies of labour movements, such as the excellent attempt by Hans Mommsen, "Art. Arbeiterbewegung", in Sowjetsystem und demokratische Gesellschaft (Freiburg, 1966), vol. 1, columns 273-313. Interestingly enough Mommsen at the end introduces "national temper" as an explanatory variable in much the same way as Werner Sombart had done in the late nineteenth century. See Werner Sombart, Sozialismus und soziale Bewegung im 19. Jahrhundert (Jena, 1896). 
artisans appears to be strikingly similar across the countries dealt with in this article, the political conditions could hardly have been more diverse. A comparative study would have to address systematically the many dimensions of "the state" only sketchily outlined above and analyse them in terms both of their relationship to civil society and to political culture. Following this admittedly difficult route should enable comparative labour history to make a significant contribution to the conceptual and theoretical problems evident in current labour historiography.

The nation state is, of course, not the only appropriate unit for a study of comparative labour history. The comparison of various regions or single cities may be as promising ${ }^{68}$ Still, comparative approaches, that alone seem able to test many of the hypotheses developed in ever more case studies, should strive to treat more than two countries. ${ }^{69}$ The debates over the peculiarities of the English, over a German Sonderweg, or over American exceptionalism have often failed to enhance our understanding of the historical process. ${ }^{70}$ All too often they have taken an idealized view of the revolutionary proletariat of continental Europe or of the peaceful integration of the English working class as a yardstick against which German deficiencies, American exceptionalisms, or English peculiarities could be measured. No one has characterized this kind of superficial pseudocomparisons better than E. P. Thompson:

${ }^{68}$ For an early attempt see Asa Briggs, "Social Structure and Politics in Birmingham and Lyons", British Journal of Sociology, I (1950), pp. 67-80.

${ }^{69}$ Among the few comparative studies we have which look at two countries AngloGerman comparisons are the most numerous. This may be explained by the strong interest in and sympathy for a seemingly peaceful and integrated British working class among German observers and social scientists during the second half of the nineteenth century. This is not, however, a sufficient reason to continue the tradition. FrenchGerman or American-French comparisons may prove to be more profitable.

${ }^{70}$ On American exceptionalism see for example the overdrawn attack of Sean Wilentz, "Against Exceptionalism: Class Consciousness and the American Labor Movement, 1790-1920", International Labor and Working Class History, XXXVI (1984), pp. 1-24. On the German Sonderweg see especially David Blackbourn and Geoff Eley, The Peculiarities of German History. Bourgeois Society and Politics in Nineteenth-Century Germany (Oxford, 1984), and Jane Caplan, "Myths, Models and Missing Revolutions: Comments on a Debate in German History", Radical History Review, XXXIV (1986), pp. 87-99, and, with respect to the labour movement, Klaus Tenfelde, "Geschichte der deutschen Arbeiter und der Arbeiterbewegung - ein Sonderweg", in Der Aquädukt 1763-1988. Ein Almanach aus dem Verlag C. H. Beck im 225. Jahre seines Bestehens (Munich, 1988), pp. 469-483, and Christiane Eisenberg, "The Comparative View in Labour History. Old and New Interpretations of the English and German Labour Movements before 1914", International Review of Social History, XXXIV (1989), pp. $403-432$, which clearly demonstrates the limits of a two-country comparison. 
"And other countries," said Mr. Podsnap remorsefully. "They do how?" "They do," returned Messrs. Anderson and Nairn severely: "They do - we are sorry to be obliged to say it - in Every Respect Better. Their Bourgeois Revolutions have been Mature. Their Class Struggles have been Sanguinary and Unequivocal. Their Intelligentsia has been Autonomous and Integrated Vertically. Their Morphology has been Typologically Concrete. Their Proletariat has been Hegemonic". ${ }^{71}$

The approach sketched out in this article attempts to avoid such oversimplifications.

$"$ E. P. Thompson, "The Peculiarities of the English", in E. P. Thompson, The Poverty of Theory \& Other Essays (New York, 1978), pp. 245-301; the quote is taken from p. 247. 